\title{
KIRÁLY TIBOR IGAZSÁGA
}

\section{TIBOR KIRÁLY'S TRUTH}

\author{
Korinek László \\ az MTA rendes tagja, professor emeritus, Pécsi Tudományegyetem Állam- és Jogtudományi Kar \\ laszlo.korinek@gmail.com
}

\begin{abstract}
ÖSSZEFOGLALÁS
Király Tibor, az MTA legidősebb tagja 2020. július 11-én tölti be 100. évét. A jubiláns maradandót alkotott a felsőoktatásban, a tudományszervezésben, valamint a bűnügyi tudományok szinte minden területén. Jelen tanulmány életművének azt a kiemelkedő értékét idézi fel, amikor a koncepciós perek lezárultával elsőként érvelt a tisztességes eljárás mellett.
\end{abstract}

\section{ABSTRACT}

Tibor Kiraly is the oldest member of the Hungarian Academy of Sciences. He will be 100 years old on the $11^{\text {th }}$ July 2020 . The jubilee has produced imperishable values in higher education, in organization of research, and in almost all fields of criminal sciences. The present study recalls the outstanding achievement of his life work that he firstly argued for institutionalizing fair procedure after the conclusion of shop-window trials.

Kulcsszavak: perbeli igazság, ártatlanság vélelme, tisztességes eljárás, kínvallatás tilalma, emberi jogok

Keywords: truth in court process, presumption of innocence, fair procedure, prohibition of torture, human rights

A kriminológus számára Király Tibor munkássága óhatatlanul azt a kérdést veti fel, hogy van-e összefüggés az általa kifejtett tudományos tételek és a bünözés valósága, annak alakulása között. Ö maga büntetőjog-tudományi - főleg, de távolról sem kizárólagosan processzuális - keretek között végezte eddigi kutatásait. A közhatalmi tevékenység és a bünözés közötti kapcsolat behatóbb vizsgálata a legutóbbi évtizedekben került előtérbe (Gönczöl et al., 2006, 597-708.), így az eljárási igazságosság szerepe és jelentősége a megelőzésben a kriminológia számára is fontossá vált (Tyler, 2003). Meggyőző érvek, sőt, adatok támasztják alá, hogy 
ez az érték befolyásolja az embereknek a jogalkalmazáshoz való viszonyulását, ezáltal pedig normakövető magatartásukat is. Ilyen megközelítésben egyértelmüen kijelenthető: Király professzornak a tisztességes eljárás követelményeiröl következetesen vallott nézetei prevenciós szempontból is irányadók. Kétségtelen tény, hogy nem Király Tibor dolgozta ki a garanciális szabályokat, tartalmuk kibontásában, helyes értelmezésük és alkalmazásuk meghatározásában azonban jelentősen gazdagította az elmélet és a gyakorlat tudástárát. Példaképpen említhetők az ártatlanság vélelméről írt gondolatai (Király, 1958). Ebben a tisztelgö írásban az univerzális értékek melletti tudósi és emberi kiállását emeljük ki, annak hangsúlyozása mellett, hogy érvei a jogfejlődés szempontjából sajnálatosnak nevezhető módon ma is aktuálisak, követendők. Király Tibor már akkor - a rendszerváltozást jóval megelőző években - egyértelmủen állást foglalt a törvények uralmán alapuló büntető igazságszolgáltatás mellett, amikor ez egyáltalában nem volt magától értetődő. Ma már a tisztességes eljárás elvei a maguk közvetlenségében általánosan elfogadottak, de azok tényleges megvalósulása a kifejtendők szerint igencsak problematikus. Ezért is szükséges rámutatni a büntetőjog-tudomány kiemelkedő képviselöjének, Király Tibornak az eljárási igazságosság alapjait jogi oldalról megerősítő tudományos teljesítményére.

\section{AZ ELJÁRÁSI IGAZSÁGOSSÁG}

A kontroll-kriminológia új szempontjainak előtérbe kerülése óhatatlanul ráirányította a figyelmet az állam és az önkormányzatok szerveinek magatartására, a terheltekhez és másokhoz való viszonyulására. A kereteket döntően az eljárási normák határozzák meg. Ha tehát a közhatalom és az emberek közötti interakciónak a bünözés kezelése körében jelentőséget tulajdonítunk - márpedig ez a helyzet -, akkor a processzuális szabályok és azok alkalmazása rendkívül fontossá válik. Azt lehet mondani, hogy a tisztességes büntető igazságszolgáltatás még az anyagi igazság megállapításának követelményét is felülírja. Ahogyan azt a magyar Alkotmánybíróság kifejtette:

„Az anyagi igazság érvényesülésére éppúgy nem biztosít (nem biztosíthat) alanyi jogot az Alkotmány, mint ahogy arra sem, hogy egyetlen bírósági ítélet se legyen törvénysértő. Ezek a jogállam céljai és feladatai, amelyek megvalósulása érdekében megfelelő - elsősorban eljárási garanciákat nyújtó - intézményeket kell létrehoznia és az érintett alanyi jogokat garantálnia. Az Alkotmány tehát az anyagi igazság érvényre juttatásához szükséges és az esetek többségében alkalmas eljárásra ad jogot." Hangsúlyozni kell, hogy ez a megállapítás sem tagadja a valóság feltárásának szükségességét, csupán annak feltétlen kikényszeríthetöségét nem ismeri el, nyilvánvalóan helyesen. Ezért a tétel nem ütközik Király Tibornak a Büntetöitélet a jog határán címü müvében lefektetett gondolataival. 
Az emberek az eljáráson keresztül kapcsolódnak a büntető igazságszolgáltatáshoz. Éppen ezért kiemelkedő jelentősége van a velük való bánásmódnak. A közhatalmi normákat is a hatóságok, ügyészségek és bíróságok tagjainak a magatartása közvetíti mindenki felé, beleértve a média útján vagy éppen nyilvános tárgyaláson hallgatóként való részvétel útján szerzett tapasztalatokat. A törvényes, tisztességes állami cselekvés tehát rendkívül fontos. Az eljárási igazságosság azonban ennél többet jelent. Helyesen mutatnak rá a kérdéssel foglalkozó kutatók, hogy a személyes részvétel, a döntések kialakítására gyakorolható befolyás teremti meg a lehetőséget a normák belsővé tételére. A processzus útján, annak értékeit is elsajátítva kerülhetnek közelebb az emberek az érdemi elvárások megértéséhez. A dolog persze nem egyszerü, de a mondottakkal összhangban juthatnak el a résztvevők és mások is a normakövetésben odáig, ami például az emberölés esetében magától értetődik: nem azért tartózkodunk a magatartástól, mert ellenkező esetben megbüntetnek, hanem azért, mert a törvénytől függetlenül is elítéljük mások életének a kioltását (Tyler, 1990).

Király Tibor számára alapkérdés ugyan, hogy milyen módon és mennyire lehet megközelíteni az anyagi igazságot, de nem bármi áron. Ez nem értelmezhető úgy, hogy a tisztességes eljárás követelményeit pusztán akadályként értelmezné. Világosan látja annak a jelentőségét, hogy a processzus nem kizárólag egy megismerési folyamat, hanem a hatalom gyakorlása is (Király, 1972, 311.). Annak a jelentősége, társadalmi hatása túlmutat az elkövetők azonosításának és megbüntetésének a szükségességén. „Ha a büntetőeljárásban megtartják az általánosan, nemzetközileg is elfogadott elveket; ha a bizonyítás nem aljasodik kényszervallatássá, a védő meri ellátni tisztét, és a bíró megőrzi méltóságát, bizalmat kelt az igazságszolgáltatás iránt és reményt gyúitt az ítéletre várókban.” (Király, 1972, 312.) Ez az eljárási igazságosság lényege. Az ítélethez vezető folyamatban az eljáró szervek értékeket közvetítenek, amelyek hatással vannak az emberek - nem csupán a terheltek - gondolkodására, és azon keresztül a magatartásukra is. Az idézett - magától értetődőnek tűnő - elvi követelmények sajnálatos módon nem a mind teljesebb megvalósulás irányába fejlődnek, noha az felelne meg a kívánatos trendnek. Érdemes olvasni Király Tibor munkáit: neki van igaza.

\section{A BÜNTETŐELJÁRÁS CÉLJA}

Nehéz, sőt megalapozottan nem is lehet cáfolni azt, amit az ünnepelt a büntetöeljárás céljaként meghatározott. Eszerint az nem más, mint az igazság megállapítása, de a mondottak szerint nem bármi áron (Király, 1972, 139.). A valóság leképezése az ítéletben egyesek szerint nem lehet abszolút mérce, az igazság nem mindenkinek ugyanazt jelenti. Ebben az írásban inkább a kijelentés második felével, az eljárási garanciák kérdésével foglalkozunk. 
Többről van szó, mint a tisztességes eljárás jogilag is értelmezhető követelményeiről. Azok természetesen kiindulási alapot képeznek, de az ítélkezésig terjedő folyamat elfogadottsága az abban tanúsított emberi magatartásoktól függ. Ki lehet jelenteni, hogy Király Tibor felismerte, sőt hangsúlyozta az eljárási igazságosság fontosságát. Ennek az eszmének ugyanis az a lényege, hogy a személyt nem szabad tárgyként, eszközként használni még akkor sem, ha ilyen módon tudnánk megközelíteni az anyagi igazságot.

Egy régi szovjet filmben a bürokrata főhős az utcán halad, miközben mindenki más ellenkező irányba megy. Valaki megkérdezi tỏle: Elvtárs, a tömegekkel szemben? A válasz: Nem, a tömegek jönnek velem szemben. A tények ismeretének hiányában nem lehet azt mondani, hogy biztosan nem lehetett igaza. A történelem számos példát szolgáltatott arra, hogy akár hatalmas méretủ politikai-társadalmi mozgásokkal szemben azokra kellett volna hallgatni, akik a veszélyekre figyelmeztettek.

\section{A TISZTESSÉGES ELJÁRÁS}

Azt a következtetést, hogy Király Tibor nem a hatóságok és a bíróságok megismerő tevékenységét korlátozó tényezők visszaszorítása útján látta megvalósíthatónak az anyagi igazság feltárását célzó eljárás sikerét, már az 1962-ben megjelent munkájában is teljesen világossá tette. A védelem és a védö a büntetöügyekben címmel megjelent könyvében éppen a tisztességes eljárás fontos követelményeivel foglalkozik. Nem szorul bővebb bizonyításra, hogy az 1956-ot követő, számos esetben enyhén szólva is kétséges törvényességủ perek többségének lezárását követően szükségessé vált a konszolidált szocializmus büntetőeljárásának szabályozása. Ez természetesen nem azt jelenti, hogy Király Tibornak a korábbi jogtipráshoz köze lett volna. Ellenkezőleg, az általa képviselt értékek kifejtése egyértelmü állásfoglalást jelentett a garanciákat sokszor nélkülöző jogalkalmazással szemben.

A konszolidált szocializmus kifejezés sem arra utal, hogy a jubiláns valamiféle markánsan kommunista, a fejlett alkotmányos demokráciák megoldásaitól gyökeresen eltérő rendszer kialakítását szorgalmazta. Valójában éppen a tisztességes eljárás elvi követelményeinek a politikai különbségektől a szakmai egység irányába történő elmozdítása olvasható ki igényként a védelemről szóló munkában. Király Tibor hangsúlyozta az ártatlanság vélelmének fontosságát, a kontradiktórius megoldások előnyben részesítését a közhatalomtól való kiszolgáltatottságot megtestesítö inkvizitórius módszerekkel szemben.

Sajnálatos, hogy a tisztességes eljárásnak az Emberi Jogok Egyetemes Nyilatkozatától kezdődően vitathatatlanul univerzális, de már korábban is megfogalmazott követelményeit nem csupán fejlesztették a már jelzettek szerint, hanem azok 
tényleges leépítése is megfigyelhető. A két tendencia csak látszólag mond ellent egymásnak. A jogvédelem erősítése a kifejezetten erre rendelt szervek tevékenységében megy végbe, míg a bünüldözést érintő politikai és szakmai elöírások, így azután maga a tevékenység is számos esetben intézményesen kérdőjelezi meg a tisztességes eljárás alapvető elveit. Sajnos világszerte.

A szervezett bünözés, valamint a terrorizmus jelenségeinek elterjedése és romboló hatásuk fokozódása miatt a 20. század végétől a politikusok úgy érezték és érzik - nem teljesen alaptalanul -, hogy lépéskényszerbe kerültek. Az emberek határozott válaszokat vártak a békeidőben eddig soha nem tapasztalt fenyegetésekkel szemben. Sokféle intézkedés, rendelkezés született a maffia típusú bünözés, valamint a politikai erőszak ellen. Ezek közös jellemzöje, hogy a veszély fennállása nem engedte meg a tudományosan és társadalmi vitákon keresztül kiérlelt megoldások bevezetését, azonnali reagálásra volt szükség. Elötérbe kerültek azok a sztereotípiák, amelyek a leglátványosabb, ámbár nem feltétlenül hatékony változtatásokkal próbálták javítani a helyzetet. Ilyen például a rendőrség létszámának növelése, a bevándorlás korlátozása és sok más közhatalmi újítás. Ezek sorába illeszkedik az eljárási jogok szükítése egyes csoportokkal és gyanúsítotti kategóriákkal szemben. A védelemhez való jog és más terhelti jogérvényesítési garancia megnyirbálása a bosszúra szomjas emberek kívánságának tett eleget. Bekövetkezett az is, amit Király Tibor a már hivatkozott 1972-es munkájában is visszataszító példaként említett: a kínvallatás újbóli bevezetése (SSCI, 2014). Méghozzá alkotmányos köntösbe öltöztetve, vagyis legitim eszközként történö alkalmazását szorgalmazva. Nem csupán a diktatúrákban, hanem a törvények uralmát hirdető rendszerekben, a demokratikus jogállamokban is (Dershowitz, 2002; Brugger, 2000).

\section{AZ ÁRTATLANSÁG VÉLELME}

A tisztességes eljárás ezen elvi követelménye visszatérő téma Király Tibor müveiben. Már 1958-ban részletesen kifejtette álláspontját a vélelem természetét és jelentőségét illetően. Ez utóbbival kapcsolatban az akkori szocialista hatalomgyakorláshoz kötődő egyes ellenvéleményekkel szemben nagyon határozottan leszögezte: „A szocialista jog nem dobálhatja ki az ablakon a demokratikus intézményeket és elveket azzal a felkiáltással, hogy liberális szaguk van. Ilyen eljárással az egész büntető eljárási jogot meg lehetne fosztani mostani demokratikus és ezzel szocialista jellegétől is." (Király, 1958, 280.)

A „liberális szag” a mai politikai viszonyok között is többek számára negatív minősítést eredményez. Az ártatlanság vélelmét ugyan közvetlenül nem érik támadások, de érvényesülése több területen is problematikus, a vele összefüggö, jórészt belőle fakadó követelményekkel együtt. Az eljárási igazságosságot ala- 
pozza meg Király Tibor következő megállapítása: „A terhelt - az ellenkező bebizonyításáig - a törvény szerint ártatlan. Ebből következik, hogy öt ügyfélként kell kezelni, úgy kell vele bánni, mintha ártatlan volna. Az ártatlanság vélelme végső fokon a büntető eljárás egyik alapelve.” (Király, 1958, 279.)

\section{ZÁRSZÓ}

Mint a fentiekből kitünik, a jubiláns a koncepciós perek utolsó hullámaival egy időben már felemelte szavát a jogállamiság, a tisztességes eljárás, a kínvallatás tilalma mellett. Elévülhetetlen érdeme, hogy ezek az örök érvényű igazságok újra visszakerültek a magyar jogi közgondolkodásba. Ezek olyan értékek, amelyeket minden jogászi generációnak illik emlékezetébe vésni, ahogy azt is, hogy Király Tibor milyen nagy szolgálatot tett a magyar jogi közgondolkodásnak.

\section{IRODALOM}

Brugger, W. (2000): Vom unbedingten Verbot der Folter zum bedingten Recht auf Folter? Juristenzeitung, 4, 165-216. https://www.jstor.org/stable/20825265? seq=1

Dershowitz, A. M. (2002): Why Terrorism Works. New Haven-London: Yale University Press

Gönczöl K. - Kerezsi K. - Korinek L. et al. (szerk.) (2006): Kriminológia - Szakkriminológia. Budapest: Complex Kiadó, 597-708.

Király T. (1958): Az ártatlanság vélelme. Jogtudományi Közlöny, 7, 277-289.

Király T. (1962): A védelem és a védő a büntetöügyekben. Budapest: Közgazdasági és Jogi Könyvkiadó

Király T. (1972): Büntetöítélet a jog határán. Budapest: Közgazdasági és Jogi Könyvkiadó

Király T. (1987): Mit ér az ártatlanság vélelme? Magyar Jog, 12, 1019-1026.

SSCI - Senate Select Committee on Intelligence (2014): Committee Study on the Central Intelligence Agency's Detention and Interrogation Program. Washington D. C.: US Senate, https:// www.feinstein.senate.gov/public/index.cfm/senate-intelligence-committee-study-on-cia-detention-and-interrogation-program

Tyler, T. (1990): Why People Obey the Law? New Haven-London: Yale University Press

Tyler, T. (2003): Procedural Justice, Legitimacy, and the Effective Rule of Law. Crime and Justice, 30, 283-357. https://www.jstor.org/stable/1147701?seq=1 